\title{
Albumin (but not Alvin) and the chipmunks help protect our brain!
}

\author{
Nathaniel B. Langer, MD, MSc, and Hiroo Takayama, MD, PhD
}

\footnotetext{
From the Division of Cardiac, Thoracic, and Vascular Surgery, Columbia University College of Physicians and Surgeons, New York, NY.

Disclosures: Authors have nothing to disclose with regard to commercial support.

Received for publication Feb 28, 2018; accepted for publication March 6, 2018; available ahead of print March 28, 2018.

Address for reprints: Hiroo Takayama, MD, PhD, Division of Cardiac, Thoracic, and Vascular Surgery, Columbia University College of Physicians and Surgeons, 177 Fort Washington Ave, 7GN-435, New York, NY 10032 (E-mail: ht2225@cumc.columbia.edu).

J Thorac Cardiovasc Surg 2018;156:539-40

$0022-5223 / \$ 36.00$

Copyright (C) 2018 Published by Elsevier Inc. on behalf of The American Association for Thoracic Surgery https://doi.org/10.1016/j.jtcvs.2018.03.014
}

Deep hypothermic circulatory arrest (DHCA) is one of the fundamental techniques for cerebral protection during complex aortic or congenital cardiac operations. ${ }^{1}$ It has, however, been associated with increased risks of mortality and permanent neurologic dysfunction after cardiac surgery, and alternative cerebral protection strategies have reduced but not eliminated this risk. ${ }^{2,3}$ What constitutes the optimal cerebral protection strategy is a controversial topic and an area of active research; a novel method for reducing postoperative neurologic dysfunction is therefore welcome.

In their article published in the current issue of the Journal, Jiang and colleagues ${ }^{4}$ report on the neuroprotective effects of treating rats before exposure to DHCA with a specific protein associated with hibernating chipmunk albumin. For many years, we have known that hibernating mammals are resistant to ischemia-reperfusion injury, tolerating profound changes in body temperature, cerebral perfusion, and metabolism with little to no effect. Application of this unique physiology to cardiothoracic surgery is also not new, because the use of a "hibernation induction trigger" as an additive in cardioplegia and lung preservation solution has been reported. ${ }^{5,6}$ This study is, however, the first to apply this knowledge to cerebral protection. In their study, Jiang and colleagues ${ }^{4}$ injected rats with an albumin-associated hibernating chipmunkspecific protein before DHCA and found significantly decreased neurologic cell damage, decreased levels of inflammatory cytokines, and improved cognitive function relative to untreated rats that underwent DHCA or animals that were injected with naloxone, a known antagonist of the "hibernating induction trigger." These results suggest that a simple, preoperative injection is able to alter cerebral tolerance of DHCA fundamentally in this rat model. The use by Jiang and colleagues ${ }^{4}$ of postoperative neurocognitive testing is especially important to our practice of cardiac surgery, because not only catastrophic neurologic injury but also cognitive changes can profoundly impact our patients' quality of life.

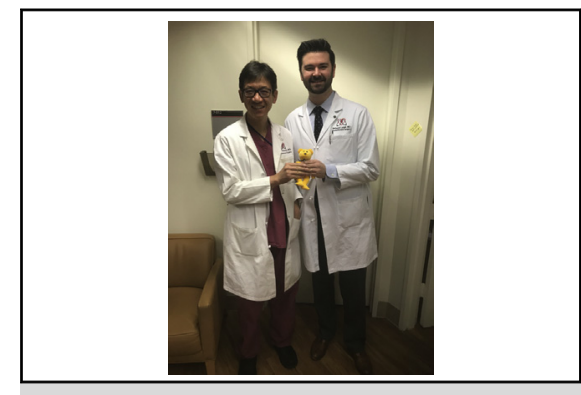

Hiroo Takayama, MD, PhD (left), and Nathaniel B. Langer, MD, MSc (right).

\section{Central Message}

Cerebral protection during complex cardiac surgery remains a challenge, and a protein from hibernating chipmunks could protect the rat brain during deep hypothermic circulatory arrest.

See Article page 525.
This novel therapy is, however, nowhere close to clinical application, and several important limitations of this work must be highlighted. The first is that it was performed in a small animal model. Although previous studies have shown that hibernation-inducing proteins do have effects in primates, ${ }^{7}$ the applicability of this biology to humans remains unknown. Second, Jiang and colleagues ${ }^{4}$ acknowledge that they do not know the molecular biology of the protein used in this study, including its amino acid sequence and structure, as well as the precise molecular functions of the protein in what are likely to be complex signaling pathways. Identification of the specific protein and a better understanding its molecular role will be essential to any future human applications.

Out-of-the-box thinking such as that in this study is to be encouraged in an attempt to significantly advance our knowledge of how best to protect the brain during complex cardiac surgery.

\section{References}

1. Ziganshin BA, Rajbanshi BG, Tranquilli M, Fang H, Rizzo JA, Elefteriades JA Straight deep hypothermic circulatory arrest for cerebral protection during aortic arch surgery: safe and effective. J Thorac Cardiovasc Surg. 2014;148:888-98; discussion 898-900.

2. Halkos ME, Kerendi F, Myung R, Kilgo P, Puskas JD, Chen EP. Selective antegrade cerebral perfusion via right axillary artery cannulation reduces morbidity and mortality after proximal aortic surgery. J Thorac Cardiovasc Surg. 2009; 138:1081-9. 
3. Misfeld M, Leontyev S, Borger MA, Gindensperger O, Lehmann S, Legare JF, et al. What is the best strategy for brain protection in patients undergoing aortic arch surgery? A single center experience of 636 patients. Ann Thorac Surg. 2012;93:1502-8.

4. Jiang X, Gu T, Liu Y, Wang C, Shi E, Zhang G, et al. Protection of the rat brain from hypothermic circulatory arrest injury by a chipmunk protein. $J$ Thorac Cardiovasc Surg. 2018;156:525-36.
5. Bolling SF, Tramontini NL, Kilgore KS, Su TP, Oeltgen PR, Harlow HH. Use of "natural" hibernation induction triggers for myocardial protection. Ann Thorac Surg. 1997;64:623-7.

6. Oeltgen PR, Horton ND, Bolling SF, Su TP. Extended lung preservation with the use of hibernation trigger factors. Ann Thorac Surg. 1996;61:1488-93.

7. Myers RD, Oeltgen PR, Spurrier WA. Hibernation "trigger" injected in brain induces hypothermia and hypophagia in the monkey. Brain Res Bull. 1981;7:691-5. 